\title{
視野中に於ける光源の位置と殘像
}

\author{
東京帝大心理學硎究室
}

真 邊 春藏

\section{I. 問題の墢生}

1932 年 7 月より 9 月に互り, 余は千輪助数授指導の下に足尾銅山に於いて坑內作業 場の照明, 溫度, 濕度, 空氣の冷却力, 風速等の作業條件と坑內作業方法の研究とを行つ た。其際，坑內に於ける照明は忽かせになし得ない間題である事を見出した。と云らのは 坑內の採鑛作業場に於いては專らカーバイトを使用する三菱式のカンテラを使用し，カン テラの焰こよつて盛に残像が起り，作業つ際甚しく明哯を好げるからである。又，坑道を 往復する場合に於いても周圍が暗黑のために焰に上る眩媈と殘像に妨げられ，明視の困難 は勿論殘像に注意が奪はれ，堅坑に於ける梯子の军降，險岨なる斜面の登降に思はぬ危險 を感ずることがしばしば女る。從つて此種の對策を講ずる事は真に必要の事と思ひ, 先づ, 親野の如何なる位置に光源を置いたならば比較的に殘像を少くし得るかに就いての賽驗を 行つた。郎ち光源としては實際坑內に於いて使用するカンテラを用ひ，視野の中心とそれ を左右水本に隔ること $30^{\circ}$ 宛の個所に光源を置き殘像の持續時間と殘像の現れ方を觀,更 に進んで對策の考究へ進んだ。

\section{II. 實驗}

實驗は東大心理學研究室內暗室に於いて行らっっ 光源としては三菱式カンテラの焰を用ひ た。焰の長さは $5 \mathrm{~cm}$ とした。

光度計で測定した結果約 10 燭光に相當した。焰の形狀は上弦の三日月形凶で女る。 カンテラを $30 \mathrm{~cm}$ 本方の內外面共黑色エナメルを塗布した金屬箱內に納め，箱の一側面 に開孔直徑 $10 \mathrm{~cm}$ の寫檤用シャターを取付けた。

被驗者が焰を見るときには此シャターの中にもの如く焰が納つてみえる樣になつてる る。焰の露出時間は 5 秒，刺戟の現れる位置は水平方向の夕で視野の中央及び中央を去る こと左右へ $30^{\circ}, 60^{\circ}, 90^{\circ}$ の 7 個所, 被驗者と光源との距離は $1 \mathrm{~m}$, 光源は眼の高さに 現れる。凝視點は直巠 $1 \mathrm{~cm}$ の白圓で極めて弱い光で照らされて存在が漸く解る程度であ る。用意ハイの合圖で刺戟が現れ 5 秒の後消失する。其後残像が現れたら被驗者は電鍵 を押す。消えたら離すやうにして殘像持續時間を隣絰でカイモグラフに記錄する。殘像が 全くなくなつたら被驗者は殘像經過の樣相を記錄する。 


\section{III. 結 果}

I) 嬠像の持續時間 今，殘像の持續時間の總計を゙各位置に就いて示せば表 I の通り で女る。

表 I. 光源の位置と殘像持續時間 (單位秒)

\begin{tabular}{c|c|c|c|c|c|c|c}
\hline \multirow{2}{*}{ 位置 } & \multicolumn{3}{|c|}{ 左 } & & 中 决 & \multicolumn{3}{|c|}{ 在 } \\
\cline { 2 - 8 } 被驗者 & $90^{\circ}$ & $60^{\circ}$ & $30^{\circ}$ & $0^{\circ}$ & $30^{\circ}$ & $60^{\circ}$ & $90^{\circ}$ \\
\hline I & 0 & 2 & 24.5 & 89.8 & 3 & 2.8 & 1 \\
II & 2.4 & 9.2 & 4.6 & 39.8 & 1.4 & 6.2 & 0 \\
III & 5.8 & 0 & 11 & 24.6 & 0 & 10.4 & 17.2 \\
IV & 5.4 & 8.8 & 6.6 & 43.2 & 7.8 & 17.4 & 11 \\
V & 0.8 & 3.6 & & 44 & 16.8 & 3.2 & 13 \\
\hline 五名平均 & 2.88 & 4.72 & 9.40 & 48.08 & 5.60 & 7.80 & 8.04 \\
\hline
\end{tabular}

郎ち，光源が視野の中心に來る場合には持續時間が最大で中心を去ること $30^{\circ}$ 以上にな ると頗る小となる。

2）殘像の色 視野中に於ける光源の位置により殘像の色が相違する。毁ち，視野の 中心に於いては陰性殘像（此場合は緑青系統つ色）と陽性殘像（此場合は赤黃系統の色） が大體に於いて艾互に現れ，而も明膫な形を有してるる。30 より外側○)周邊に於いては 色は中心親に於ける程明膫ならず，色彩不明或は白色となる。色彩の明膫な殘像が現れる ときは一般に陽性殘像よりは陰性殘像の方が多い。

3) 殘像の經過 刺战が視野の中心に來る場合には, 刺战の消失值後乃至 2 秒後に陰 性殘像が現れ 10 秒乃至 30 秒の後消失し， 1 秒乃至 3 秒の後に陽性殘像が出現し，之が 消失すると再び陰性或は陽性の线像が出現しか〉る事を幾度か繰返して後消失する。殘像 の持續時間は時間の經過と共に小となり, 出現と消隇が速となり, 殘像の形は不明䐲とな つて逐に消失する。30 より外の周邊に於いては刺载消隇後殘像出現迄の時間比較的屒く 1/5 秒乃至 14 秒を要し，持續時間为少くなる。( 4 秒乃至 12 秒)。而して陽性よりは陰 性殘像の方が主として現れる。殘像の形は甚だ不明膫であつて時が經つにつれて霧の樣に なつて逐に消失する。

4）殘像の運動視野の中心に刺战が現れたる場合の殘像け必ずしも刺戟の現れたる 位置にに定位せず，運動を起す事が多い。郎ち，最も多く起る運動は左下方への運動であ つたが，其他の力向へ運動することもある。而して瞬目すると又元の位置にもどる。

\section{IV. 對 策}

以上の結果からみると坑內で探鑛作業をする場合には成可く，光源を視野の中心より外 
側約 $30^{\circ}$ 以上に置いた方がよい。坑道の往復に於いても光 源老成可く覞野の中央へ持つて來ない方が殘像が起らない。 余は光源より來る矓䊗と殘像を除かんがためにカンテラ の焰の基部心杯形の金屬製器具を取付计坑內作業者に使用 せしめたる所，眩輝，殘像の防止に役立つのみならず，鑛 石を明に視ることが出來る樣になつた，其上，風による焰 の消滅がなくなつた。

右の圖に於て器具の下方が缺けて居るのは, 作業の性質 上又心步行上，下方を明るくするためである。本器を取付 けると水滴の落下や風による焰の消隇か殆んど無くなる事 も，作業者達によつて報告せられた。

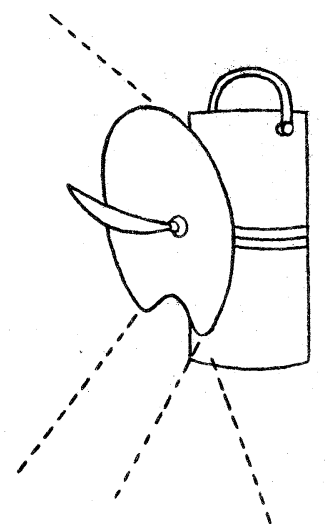

【附記】終りに臨み虽時わざわざ足尾銅山汽御出でになつて御指導賜つた千輪先生に衰 心ょり感謝の意堂する。 (1939 年 3 月 13 日原稿受附) 